\title{
Reflections from the 78th Scientific Sessions of the American Diabetes Association
}

\author{
Dr Caroline Day reports from the \\ Orlando meeting, 22-26 June 2018
}

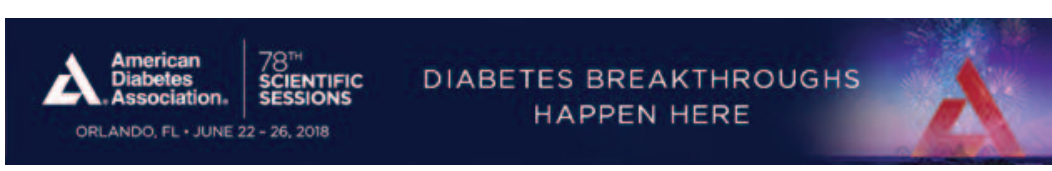

\section{An alternative Magic Kingdom?}

Hosting the 78th Annual Scientific Sessions of the American Diabetes Association (ADA) in Orlando - home to more than a dozen theme parks and waterparks - appeared an ideal opportunity to facilitate a healthy balance of work and play. The Orange County Convention Center (West Concourse, just off International Drive) provided a welcome relief from the steamy subtropical $\left(28.5^{\circ} \mathrm{N}\right)$ climate and the covered walkways linking it with major hotels (where meetings and sponsored symposia were held) offered respite from the searing sun and daily torrential rains. (It was easy to walk a twomile circuit without encountering the 'real world'). However, escapism wasn't on the agenda for more than 16,000 delegates attending this five-day meeting. They had access to over 2,500 abstracts: 375 research presentations in 49 oral sessions; display of over 2,000 posters (including 317 late breakers), with 47 selected for moderated discussion and nearly 300 published-only abstracts. ${ }^{1-3}$ There were 15 industry-sponsored symposia distributed over every evening of the conference, plus three which deterred weekend lie-ins by commencing at $5.30 \mathrm{am}$. Did someone mention an association between sleep deprivation and type 2 diabetes (T2DM)?

\footnotetext{
Awards

The award lectures provided interesting perspectives and can be viewed online (Table 1). ${ }^{4}$ Professor Gerald Shulman (Yale, USA) delivered a clearly illustrated Banting Lecture elucidating pathways culminating in insulin resistance and T2DM and paid tribute to Gerald Reaven (who died in February 2018). Reaven was the first person to postulate the critical role of insulin resistance in predicting the development of T2DM and other components of the metabolic syndrome, with consequent generation of an atherogenic milieu (ADA Banting Lecture 1988). The Outstanding Achievement Awards were bestowed upon UK recipients: Professor Laura Heisler (Aberdeen) for her work on serotonin in diabetes and obesity, including de-
}

Table 1 Awards

\begin{tabular}{ll}
$\begin{array}{l}\text { National Scientific \& Health Care Achievement } \\
\text { Awards and Lectures }\end{array}$ & Recipient \\
\hline $\begin{array}{l}\text { Banting Medal for Scientific Achievement Award } \\
\text { Lecture: Mechanisms of Insulin Resistance: Implications for } \\
\text { Obesity, Lipodystrophy and Type 2 Diabetes (24 June) }\end{array}$ & Gerald I Shulman \\
$\begin{array}{l}\text { Kelly West Award for Outstanding Achievement in Epidemiology } \\
\text { Lecture: Diabetes Diagnosis and Control: Missed Opportunities } \\
\text { to Improve Health (24 June) }\end{array}$ & Catherine C Cowie \\
$\begin{array}{l}\text { Outstanding Scientific Achievement Award } \\
\text { Lecture: Harnessing Brain Circuits to Improve Type 2 Diabetes (25 June) }\end{array}$ & \\
$\begin{array}{l}\text { Outstanding Educator in Diabetes Award } \\
\text { Lecture: Connectedness: How Technology and Social Networks } \\
\text { are Advancing Diabetes Nutrition Care (23 June) }\end{array}$ & Jackie L Boucher \\
Outstanding Achievement in Clinical Diabetes Research Award & Rury R Holman \\
Outstanding Physician Clinician in Diabetes Award & Andrew J Ahmann \\
Albert Renold Award & Mark A Atkinson \\
Harold Rifkin Award for Distinguished International Service in the & Viswanathan Mohan
\end{tabular}

Cause of Diabetes

Professional Interest Group Award Lectures

Recipient

Edwin Bierman Award (Complications)

Alessandro Doria

Lecture: Leveraging Genetics to Improve Cardiovascular Health in Diabetes (25 June)

Norbert Freinkel Award (Pregnancy)

Lecture: Metabolic Culprits in Obese Pregnancies and Gestational Diabetes: Big Babies, Big Twists, Big Picture (23 June)

Roger Pecorara Award (Foot care)

Lecture:The Ghosts of Diabetic Foot Infection: Past, Present, and Yet to Come (23 June)

Richard R Rubin Award (Behavioural Medicine \& Psychology)

Lecture: Diabetes and Behavior in the 21st Century: Things That Make You Go "Hmmm" (23 June)

Linda (Lynn) A Barbour

Edgar J Peters

Tim Wysocki

finitive mechanistic studies on the anti-obesity agent dexfenfluamine. It was noted that Professor Heisler is only the third woman to receive this award in its 62-year history. Professor Rury Holman (Oxford) was honoured especially for his well-known work on the United Kingdom Prospective Diabetes Study (UKPDS) and the UKPDS post-trial monitoring study (trials which have transformed the management of T2DM), as well as his pioneering studies on the use of basal insulin therapy in T2DM. Interestingly, he was also the co-inventor of the first automated finger-pricker (for home blood sampling), the first automated insulin pen and the HOMA calculator.

Martin Parkhoi still holds the record for the fastest 5K@ADA run, with an average pace of 4.45 miles/min at the 2011 San Diego meeting. This year's fastest runner, Maxime Bergatto, averaged 5.01 miles/min with a chip time of 15:32.7 min - just a shade faster than 
Bryan Alvarado (5.03 miles/min) at last year's meeting in San Diego. The fastest woman in this year's run was Jeanine Cordova who ranked 22nd with a chip time of 19:47.5 min.

\section{Know the story - tell it}

In her Presidential address, Jane Reusch (ADA President, Medicine \& Science) urged delegates to tell the diabetes story and to use the data (Box 1). She emphasised that the burden of diabetes is on the person and their family, and touchingly illustrated this with a case study of her father who was diagnosed with T2DM when he was 53 years old. She put the diabetes crisis in the contemporary context of other health crises, commenting on the attention afforded the opioid epidemic (which claims a life every $52 \mathrm{~min}$ ) and the funding that accompanies high profile conditions such as HIVIAIDS (eg, in $2016 \mathrm{NIH}$ funding was $\$ 3$ billion for HIV/AIDS and $\$ 1.084$ billion for diabetes, which equates to about $\$ 2,727$ and $\$ 37.25$ per affected person, respectively). The prevalence of diabetes in the USA is almost 30-fold greater than that of HIV/AIDS. Research follows the finance and this investment has transformed HIVIAIDS from a death sentence to a long-term condition. Professor Reusch noted that diabetes is massively underfunded and the challenge is to increase public awareness of risk and engage legislators to support spending for transformative diabetes research.

\section{Box 1 USA diabetes statistics}

Diabetes contributes to:

- 1 stroke every 2 min

- 1 case of ischaemic heart disease every 80 seconds

- 1 case of kidney failure every $10 \mathrm{~min}$

- 1 lower limb amputation every 5 min

- 1 death every 6.5 min

- A reduction in life expectancy of 8-23 years

More than 451 million people worldwide have diabetes - it is not extraordinary - and actions which may predispose to the condition are neither risky nor risqué, thus institutions are unlikely to be subjected to a media frenzy demanding increased spending on diabetes. Again the baton falls to those touched (professionally and/or personally) by diabetes to raise its public profile.

\section{Something different?}

Perhaps disappointingly, a major cardiovascular outcomes trial (CVOT) didn't report at this year's ADA. There were several presentations featuring sub-analyses and secondary endpoints of earlier CVOTs, but these weren't contentious. At ADA 2017 the CANVAS program observed an almost doubled incidence of below-knee amputations in patients taking canagliflozin. However, OBSERVE-4D (a realworld study of over 700,000 T2DM patients from US claims databases) did not show an increased risk of amputations in patients taking canagliflozin across the general diabetes population or in those with established cardiovascular disease, regardless of whether patients were taking a different sodiumglucose co-transporter (SGLT) 2 inhibitor or taking non-SGLT2 inhibitors. OBSERVE-4D also suggested that new users of canagliflozin had a lower risk of hospitalisation for heart failure compared with new users of nonSGLT2 inhibitors, but a similar risk to new users of other SGLT2 inhibitors. Data from the REFORM trial showed that T2DM patients with mild heart failure (CMR-LVEF $\geq 45 \%$ ) taking a regular diuretic, heart failure therapy and dapagliflozin (10 mg/day) for one year had reduced left ventricular end diastolic and end systolic volumes as well as reduced left ventricular mass.

Interest continues in the use of SGLT2 inhibitors as adjuncts to insulin therapy in type 1 diabetes (T1DM), as evidenced by the dedication of the final symposium of ADA 2018 to this topic. The DEPICT 2 (addition of dapagliflozin $5 \mathrm{mg}$ or $10 \mathrm{mg} /$ day for 24 weeks) and inTandem1 (addition of the investigational dual SGLT1 and SGLT2 inhibitor sotagliflozin $200 \mathrm{mg}$ or $400 \mathrm{mg} /$ day) studies both showed significant reductions in $\mathrm{HbA}_{1 \mathrm{c}}$ and body weight in T1DM patients with poor glycaemic control. Severe hypoglycaemia was not increased in either study. However, diabetic ketoacidosis occurred in $2.6 \%$ and $2.2 \%$ of patients on dapagliflozin $5 \mathrm{mg}$ and $10 \mathrm{mg}$, respectively, and in $3.4 \%$ and $4.2 \%$ of patients on sotagliflozin $200 \mathrm{mg}$ and 400 mg, respectively. ${ }^{5}$

Several studies reported the use of glucagon-like peptide 1 receptor agonists (GLP-1RA) as useful adjuncts to insulin therapy. For example, addition of liraglutide (1.8 $\mathrm{mg} /$ day) for 1 year to the treatment of overweight (BMI $29 \mathrm{~kg} / \mathrm{m}^{2}$ ) T1DM patients with $\mathrm{HbA}_{1 \mathrm{c}}>7.9 \%$ significantly reduced body weight, blood pressure and glycaemic control without increasing hypoglycaemia. The total insulin dose did not alter.

The ADA mini symposia (mostly on the first day of the meeting) and symposia offer overviews and updates on specialist topics as well as opportunities to focus on specific studies such as the Restoring Insulin Secretion
(RISE) in Youth and Adults Study which reaffirmed the more aggressive nature of T2DM in younger people, or the Veterans Affairs Diabetes Trial (VADT) at 15 years. After a median of 5.6 years of intensive glucose control (median between-group difference of $1.5 \% \mathrm{HbA}_{1 \mathrm{c}}$ ) in people with advanced T2DM, the post-trial follow-up (VADT-F) showed delayed benefit on cardiovascular, renal and retinal events, despite worsening glycaemic control at 10 years. Thereafter, glycaemic control was the same in both groups and there were no differences in outcomes at 15 years.

The proposed ADA-EASD consensus report on the management of hyperglycaemia in T2DM was the focus of a symposium on the last day of the meeting. The joint presentation by Chantal Matheiu and David D'Alessio provided a strategy for implementation and offered a sneak preview of the proposed algorithm (metformin remains firstline).

\section{Diary date}

ADA 2019 will be held on 7-11 June at the Moscone Center, San Francisco, California (average temperature $19^{\circ} \mathrm{C}$ with highs of $24^{\circ} \mathrm{C}\left(65^{\circ} \mathrm{F}\right.$ and $\left.75^{\circ} \mathrm{F}\right), 13$ hours of sunshine a day, sea mists but no rain); the location is enticing. Alternatively, forego the airport experience, a couple of 11-hour direct flights and conference burnout; book time off later in June to access the conference online ( $\$ 279$ for non-ADA members in 2018). Attend every session of interest at your leisure and be able to read the slides.

\section{References}

1. American Diabetes Association. 78th Scientific Sessions Abstracts. Diabetes 2018;67(Suppl 1):A1-A761.

2. American Diabetes Association. 78th Scientific Sessions Late Breaking Abstracts. Diabetes 2017; 67(Suppl 1A):LB1-LB109.

3. American Diabetes Association. Mobile App. To view via computer go to https://plan.core-apps.com/tristar_ada18 and to view via a mobile device go to https://medmtg.news/2018-app-ada-event or download 'ADA Events' from Google Play or the App Store.

4. American Diabetes Association. Accessing Scientific Sessions Webcasts 2018. https://professional.diabetes.org/webcasts-ss2018

5. Buse JB, Garg SK, Rosenstock J, et al. Sotagliflozin in combination with optimized insulin therapy in adults with type 1 diabetes: the North American inTandem 1 study. Diabetes Care 2018 Jun;dc180343. https://doi.org/10.2337/dc18-0343

Correspondence: Dr Caroline Day Visiting Fellow, Diabetes Group, Aston University, Birmingham B4 7ET, UK E-mail: cday@mededuk.com

https://doi.org/10.15277/bjd.2018.186 Br J Diabetes 2018;18:124-125 